Алгебра и анализ

Toм 21 (2009), № 5
St. Petersburg Math. J.

Vol. 21 (2010), No. 5, Pages 839-842

S 1061-0022(2010)01121-X

Article electronically published on July 15, 2010

\title{
VON NEUMANN WITH THE DEVIL
}

\author{
LARS GÅRDING
}

Run-down room, a table and two chairs. Von Neumann enters and finds himself alone. Takes a seat. Shortly, the Devil enters 1

Von Neumann. How strange. A new room. In Hell, maybe? No one here. (Pause.) I have been moved, but noticed nothing. Just like the way I arrived in Heaven.

DEviL (making a sudden entrance). I am late, as usual. There is never enough time for my Devilry.

Von Neumann (surprised). Pardon? Besides, who might you be?

Devil. Did you not hear? I am the Devil himself.

Von Neumann. Why are you late?

Devil. I told you. My Devilry.

Von Neumann. Please explain.

DEviL. My work is to carry out and maintain evil, or in other words, Devilry. With a capital "D". You have to understand that the word has a different meaning here than on Earth, where it is spelled with a lower case " $\mathrm{d}$ ". Therefore, I prefer my own spelling. It is in keeping with tradition and adds prestige to my work and myself.

VON NEUmANn. I have an important question. What is the relationship and the division of power between you and my latest partner in conversation, God? He claimed he is omnipotent, but I could not determine whether it is true.

Devil. You do not shy away from the big issues. God is omnipotent and his power extends even to Hell. Meanwhile, he often leaves his power to chance, according to his own will. With the help of chance I hold great power, almost omnipotence, here in Hell. For example, I can burn you with fire or crush you until you scream.

Von Neumann. You have no motive. I have another question. On Earth, they say you have charge over the souls of sinners, while God takes care of souls of those who have not sinned. Is this true?

Devil. Not quite. Sinners can better themselves, become forgiven and be regarded as nonsinners. Apart from these rather unusual cases, it is true that I take the sinners and God keeps those free from sin.

Von Neumann. Another question. How do you differ between the souls of sinners and nonsinners? You and God, I mean.

L. Gårding's play "Mathematics, Life, and Death" was published in Algebra i Analiz 12 (2000), no. 5 (the first part) and 13 (2001), no. 3 (the second part). [EDitorial NotE: These parts were not included in the English translation of the issues indicated.] This publication presents a new version of the meeting of von Neumann and the Devil.

${ }^{1}$ Von Neumann's meeting with God ends with God's leaving. Afterwards, a voice proclaims: von Neumann is granted an audience with the Devil. 
Devil. A sinner is a soul who did not believe in God, or did believe, but had impure thoughts. A nonsinner is the opposite.

Von Neumann. You make the definition with almost mathematical precision. However, what do you mean by impure thoughts?

DEvIL. It is a rather earthly notion and therefore particularly unclear in Heaven and Hell.

Von Neumann. In that case, I find your and God's work to be far too arbitrary and thus fairly meaningless. I mean separating the sinners from the others and the caretaking of their souls.

DeviL. That is just what you think. As you know, men are mortal, but their souls are immortal and therefore need someplace to stay. This is in the care of God and myself. It is a categorical imperative.

Von Neumann. Finally a comprehensible answer. However, you must be short on space, with so many souls born since the beginning of time.

Devil. Your thinking is limited by earthly constraints. My universe is not like the one on Earth, with planets, a Sun, et cetera. Mine is like an infinitely large bubble, somewhere in the earthly domains or just outside.

Von Neumann. You are being vague. I should probably ask more precise questions. Please be honest. First of all: how old are you?

DeviL. I existed always.

Von Neumann. What brings meaning to your life? What joys, what sorrows?

DEviL. I do not need meaning in life. Devilry goes on regardless. Joys? There are none. The Devil cannot be joyful. The same thing with sorrows, although sometimes there are some.

Von Neumann. You are quite unspecific. What were you doing before coming here today?

DEviL. I made a golfer miss an important shot. To my satisfaction, he was furious.

Von Neumann. Illustrative, but it seems rather petty for the Devil himself.

DeviL. Not at all! The golf mischief was just in passing, after orchestrating a large train crash. Here in Hell, we do not discriminate between big and small. We deal with everything as it comes.

Von Neumann. If you excuse me, I am starting to think I have learned enough for now. I would like to leave (tries to rise from the chair, but fails).

DeviL. Interesting. This was no Devilry of mine. It must be God's will acting in Hell, to stop you from straying from his path. This happens sometimes, as I already told you.

Von Neumann. I might as well go on asking you about Hell. According to Dante's description, there should be a Limbo here and a Purgatory, made up of nine terraces with different torments leading the purged sinners to Heaven. Speaking of which, God never told me about the nine corresponding terraces up there. 
Devil. That model is obsolete nowadays, although the Limbo remains. Purgatory used too much energy and has been closed and replaced with a section for thorough interrogation of sinners, bordering on torture. Today most of Hell has become an immense retirement home, with nurses and recreation. Nothing else would have been economically tenable. A small gate to Heaven still exists as well, difficult but not impossible to find. Heaven often gets interesting newcomers entering through it. The terraces up there are gone too, rationalized away.

Von Neumann. Your Hell reminds me of modern earthly societies. Dante's was much more interesting.

Devil starts looking nervous.

DeviL. I hear the archangel Gabriel, a part-time deputy at the main gate, is having trouble with a crowd of souls absolutely adamant on going to Heaven, in spite of Gabriel's depiction of life there in the most dreary terms. If you will excuse me, I have to go out and endorse Hell as a place of residence.

Devil disappears, von Neumann is alone.

Von Neumann (alone). I feel rather tired after conversing and moving about. Perhaps Limbo could be the place for me. Maybe there I could think of my mathematics in peace. (Pause.) That Devil does not seem like an unreasonable fellow.

DEVIL (returns panting). It did not work. At least we managed to get them to sit down and reason.

Von Neumann. Tell me about Limbo.

Devil. It is a kind of tourist resort. Souls in Heaven that tire of the constant psalm singing can go there to relax. You can meet interesting souls there, like Newton, Torquato Tasso, Gauss, Selma Lagerlöf, Sonya Kovalevskaya, and many others. Why not Goethe?

Von Neumann. I would like to meet Hilbert again and maybe Courant. Their souls I mean.

Devil. They will certainly come, if you just wait. You will have plenty of time for that. By the way, I overheard you mumbling to yourself that you need some rest. Your wish is granted!

Both disappear from the stage, a short pause and then psalms echo in the distance.

A change of scenery to Limbo. A better table, all else the same. Two old mathematicians, Hermann Weyl and Richard Courant look bored sitting at the table (yawning, etc.)

WEYL. I suppose von Neumann should be here any minute.

COURAnt. A brilliant mathematician.

WEYL. But a generation younger than ourselves. That could be problematic.

Courant. Although perhaps entertaining.

Von Neumann enters accompanied by the Devil.

Von Neumann. Look, two old friends from Göttingen, a long time ago.

DeviL. My friends as well, after a small dispute on priority. Held between gentlemen and therefore not widely advertised, almost kept secret. Although not from me and my power, derived from God's omnipotence after all. 
Von Neumann. Gentlemen, this is the Devil himself on a brief visit. What was your priority dispute about?

WEYL. A trifle. A property of the sequence of eigenvalues of operators.

Von Neumann. It follows from my generalization of Hilbert's theorem.

Courant. But the priority is mine.

WEYL. No, mine!

Von Neumann. Gentlemen, enough! You are playing into the Devil's hands. It just makes things worse.

WEYL. I was not the one who started it!

Courant. Neither was I!

Von Neumann. I implore you to forget the whole thing. I am changing the subject!

Devil disappears.

Von Neumann. The new subject will be: has the Devil any place in mathematics?

WEYL. Of course. We think in terms of hypotheses and proof. Sometimes it all goes to Hell, when we overlook some detail and wish too hard for beautiful results. In difficult cases, we think this is the Devil's handiwork.

Courant. I agree. When we are in Heaven, it is natural to blame the Devil. But it must be done quietly and discreetly. In Heaven, as you know, he cannot be mentioned by name.

Von Neumann. Interesting, though your point contradicts my experience. I have to say that I have never forgotten an important detail in my work. By the way gentlemen, how long shall I enjoy your company?

WEYL. We are leaving for Heaven in a moment. We live there, on the second terrace. Our stay in Limbo is ending. We were short on interesting new acquaintances until von Neumann came. Our meeting was fortunate.

Von Neumann. I am flattered. Meanwhile, I feel it is God's will that I should stay here.

WEYL. Enjoy yourself! With luck, you may look forward to some interesting conversation.

Weyl and Courant disappear, Von Neumann is left alone.

Von Neumann (upset). So there are terraces in Heaven! The Devil lied! (Pause, then thoughtfully.) Maybe I have a future after all. Maybe even in the seventh Heaven, if I play my cards right. There I do not know, but it should be a nice place. A big library... fast computers... interesting people...

Perhaps those are just my earthly hopes. (Stops abruptly, sits still and quiet.) The curtain falls.

Received 11/OCT/2008

Translated from the Swedish original by MICHAEL V. MAZYA 